ppi $201502 Z U 4645$

Esta publicación cientifica en formato digital es continuidad de la revista impresa ISSN-Versión Impresa 0798-1406 / ISSN-Versión on line 2542-3185Depósito legal pp

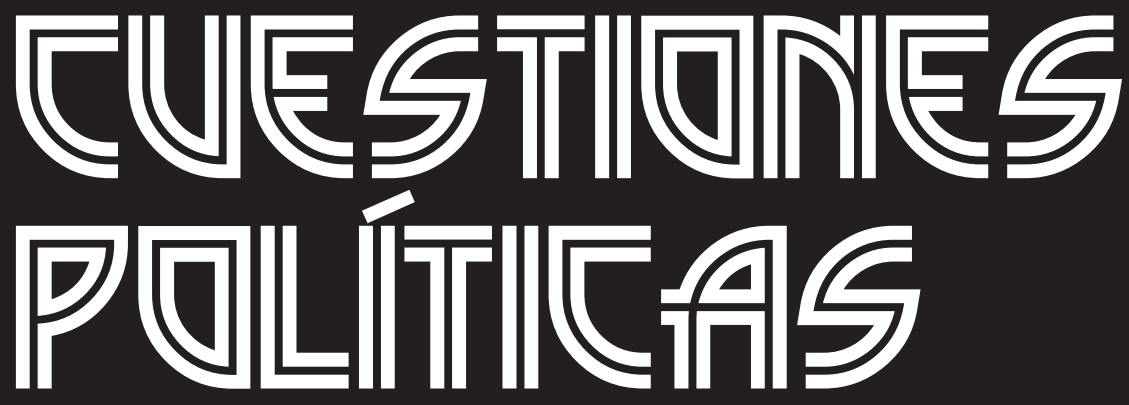

Instituto de Estudios Políticos y Derecho Público "Dr. Humberto J. La Roche' de la Facultad de Ciencias Jurídicas y Políticas de la Universidad del Zulia Maracaibo, Venezuela
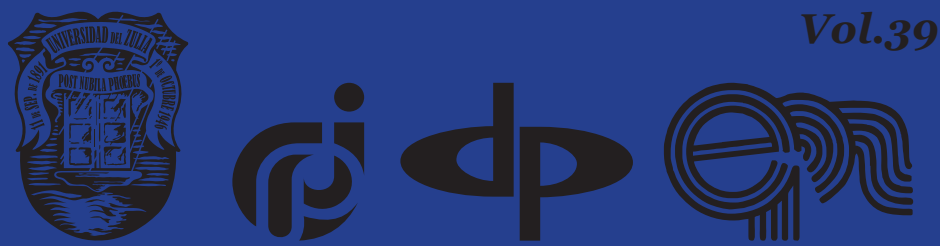


\title{
International Experience in Assessing the Effectiveness of Law Enforcement Agencies in Crime Prevention
}

\author{
DOI: https://doi.org/10.46398/cuestpol.3968.21
}

\author{
Vira Halunko * \\ Oleh Shkuta ** \\ Oleh Predmestnikoy *** \\ Nataliia Petrenko **** \\ Nina Holenko *****
}

\section{Abstract}

The objective of the investigation was to analyze some international experience in assessing the effectiveness of law enforcement in crime prevention. Methodologically, the dialectic method, typical of materialistic philosophy, was combined with scientific techniques of cognition. It is concluded that the basis for assessing the effectiveness of law enforcement agencies in different countries is based on a set of quantitative and qualitative criteria; sometimes such criteria conflict with each other, as some are beneficial for bureaucratic reporting, while others reflect the public's interests. Public opinion, as one of the main criteria, is becoming increasingly important in assessing the effectiveness of law enforcement agencies in some countries (e.g., the Slovak Republic), and in the US, France, Japan, Austria, and Italy, it is a traditional evaluation tool. Ambiguous is the use of statistics to assess the effectiveness of law enforcement in certain countries and Finally, there are countries where criminal statistics are a priority to determine the effectiveness of law enforcement and in others not.

* Vira Halunko, Professor, Doctor of Science in law, Professor at the Department of Professional and Special Disciplines of Kherson Faculty, Odesa State University of Internal Affairs, Kherson, Ukraine. ORCID ID: https://orcid.org/oooo-0002-0563-0576. Email: vera.galunko.0o@gmail.com

** Oleh Shkuta, Professor, Doctor of Science in law, Professor at the Department of Professional and Special Disciplines of Kherson Faculty, Odesa State University of Internal Affairs, Kherson, Ukraine. ORCID ID: https://orcid.org/oooo-0oo3-0395-5710. Email: oleh_shkuts@ukr.net

*** Oleh Predmestnikov, Doctor of Science in law, Professor at the Department of Professional and Special Disciplines of Kherson Faculty, Odesa State University of Internal Affairs, Kherson, Ukraine. ORCID ID: https://orcid.org/oooo-ooo1-8196-647X. Email: predmestnikov@ukr.net

**** Nataliia Petrenko Candidate of Science in law, Associate Professor at the Department of Professional and Special Disciplines of Kherson Faculty, Odesa State University of Internal Affairs, Kherson, Ukraine. ORCID ID: https://orcid.org/oooo-0002-9641-718X. Email: naturlix84@ gmail.com

***** Nina Holenko, Candidate of Science in law, Associate Professor at the Special Phisical and Weapons Training of Kherson Faculty, Odesa State University of Internal Affairs, Kherson, Ukraine. ORCID ID: https://orcid.org/oooo-ooo1-8743-4765. Email: nino4ka.golenko@ukr.net 


\section{4}

Vira Halunko, Oleh Shkuta, Oleh Predmestnikov, Nataliia Petrenko y Nina Holenko

International Experience in Assessing the Effectiveness of Law Enforcement Agencies in Crime Prevention

Keywords: international experience in public order; control and evaluation; law enforcement agencies; crime prevention policies; criteria for the evaluation of lawenforcement.

\section{Experiencia internacional en la evaluación de la eficacia de las fuerzas del orden en la prevención del delito}

\section{Resumen}

Elobjetivo dela investigación fue analizar cierta experiencia internacional en la evaluación de la eficacia de las fuerzas del orden público en la prevención del delito. En lo metodológico se combinó el método dialectico, propio de la filosofía materialista, con técnicas científicas de cognición. Se concluye que la base para evaluar la efectividad de las agencias de aplicación de la ley de distintos países se sustenta en un conjunto de criterios cuantitativos y cualitativos; a veces, tales criterios entran en conflicto entre sí, dado que algunos son beneficiosos para la presentación de informes burocráticos, mientras que otros reflejan los intereses del público. La opinión pública, como uno de los criterios principales, se está volviendo cada vez más importante para evaluar la efectividad de las agencias de aplicación de la ley en algunos países (por ejemplo, la República Eslovaca), y en los EE. UU., Francia, Japón, Austria e Italia, es una herramienta tradicional de evaluación. Ambiguo es el uso de estadísticas para evaluar la eficacia de las fuerzas del orden de ciertos países y; finalmente, hay países donde las estadísticas penales son una prioridad para determinar la eficacia de las fuerzas del orden $\mathrm{y}$ en otros no.

Palabras clave: experiencia internacional en orden publico; control y evaluación; agencias de aplicación de la ley; politicas de prevención del delito; criterios de evaluacion de las fuerzas del orden público.

\section{Introduction}

The study of the administrative and legal basis for the effectiveness of assessing the activities of law enforcement agencies as subjects of financial and economic security of Ukraine is impossible without a detailed study of the experience of foreign countries in this area. Today, the urgency of this issue is justified by the fact that Ukraine largely imitates the activities of law 
enforcement agencies of the EU countries, in particular, in accordance with European models, law enforcement agencies, prosecutors, NABU and DBR of Ukraine have been reformed, however, no attention is paid to assessing the effectiveness of these entities.

In general, researchers note that the assessment of the effectiveness of law enforcement agencies of foreign countries is based on information obtained from the study of the following areas: criminal statistics (number of crimes per person, number of people serving sentences, the number of detected crimes); the results of public opinion polls (the results of surveys of citizens' satisfaction with the work of law enforcement agencies, the results of surveys of victims, representatives of government agencies that interact with law enforcement agencies); the results of control exercised by supervisory authorities; results of public control; reports of the Commissioner for Human Rights; statistics of appeals to law enforcement agencies, the content of these appeals; the level of corruption in law enforcement agencies; establishing the number of law enforcement officers and their ratio to the population; establishing the number of private security structures and their ratio to the number of law enforcement systems (the higher the number of private security structures, the lower the efficiency of the law enforcement system); systems of replacement of positions in law enforcement agencies - appointment or competition; financing system (when assessing the results of work correlate the cost of maintaining law enforcement agencies with the amount of averted or already compensated damage; economic factor (the effectiveness of the law enforcement system can be defined as the maximum reduction in crime for a given budget costs of such activities).

\section{Literature review}

Based on the above, it is obvious that significant attention is paid to public opinion polls, the results of public control and consideration of citizens' appeals, which indicates the orientation of law enforcement agencies to the needs of citizens. This trend is especially noticeable today in the activities of the police, according to which the police of more democratically developed countries generally prefer the principles of "community policing". Whereas states where democracy has only just begun to emerge (Eastern Europe, Central Asia), whose legislation is transitional and whose mechanism is characterized by the remnants of communism, are more likely to adhere to the principles of "zero tolerance" in policing (Lum, 2009).

Back in 1996, American scientists generalized the benefits of following the principles of "community policing", including: 


\section{6 \\ Vira Halunko, Oleh Shkuta, Oleh Predmestnikov, Nataliia Petrenko y Nina Holenko \\ International Experience in Assessing the Effectiveness of Law Enforcement Agencies in Crime Prevention}

1. reducing the crime rate;

2. increasing the level of transparency of police activities;

3. increasing the level of citizens' satisfaction with the police;

4. reducing the level of complaints about the activities of police officers;

5. increase the satisfaction of police officers with their work;

6. involvement of the public in the activities of police bodies;

7. improving the efficiency of police activities and the quality of performance of tasks assigned to police officers (McCold and Wachtel, 1996).

O. V. Gordeev draws attention to the fact that, despite the different traditions and historical experience in countries such as the United States, France, Japan, Austria and Italy, constant public opinion polls are the main tool for assessing the law enforcement agencies of these countries. Moreover, for such states the issue of improving the forms of social control over the activities of law enforcement agencies as guarantors of respect for universal rights and freedoms remains relevant (Gordeev, 2017).

\section{Materials and methods}

The basis of the study is philosophical methods: dialectical (the basic principles of which are objectivity, comprehensiveness, concreteness and completeness of knowledge, division of the united and knowledge of its contradictory sides etc.), logical (the main methods of which are analysis and synthesis, induction and deduction, analogy, ascent from concrete to abstract and from abstract to concrete), etc.

Among the scientific methods of cognition are used methods of system analysis (structural, functional, factor, genetic), target, typological, model. With regard to the knowledge of the realization of the human right to protect the law, the method of institutional analysis allows us to justify the contours of the real field of the implementation of the human right to protect the law as a single integrated legal institution, which is very valuable for identifying the laws of its functioning and improvement; classify the funds it contains into organizational and legal ones; to examine each organizational or legal means in terms of its adequacy to the meaning and purpose of the human right to protect the law, as well as its functional orientation to achieve its goal - to eliminate the threat to human rights security or restore it. 


\section{Results}

In the states of Europe and the USA the basic models of law enforcement activity, and accordingly also models of trust of citizens to law enforcement agencies are already formed. In particular, the European model operates in conditions of social tolerance, the American - more focused on the principles and values of social identity. There is also a third model the Eastern, which traces a system of religious restrictions and taboos (Loshitskyii, 2015).

In particular, in the Slovak Republic, the Minister of the Interior, together with the Institute for Public Opinion Research, developed an official questionnaire to determine the level of public confidence in policing in various fields and to identify the reasons influencing their position, which was called "Social status and role of the police in the opinion of the citizens of the Slovak Republic". This is an example of existing models for finding out the trust of citizens in the police, other law enforcement agencies, etc. However, this is only the first steps of the Slovak Republic in this direction, given that according to a 2017 Eurobarometer survey, the highest level of distrust in the police was observed in the Slovak Republic, which is about $53 \%$ of the population who expressed this opinion. For example, the lowest level of distrust in the police among EU countries in Austria, about 11\%, although for EU member states the average is 23\% (Andriichenko, 2018).

At the same time, such involvement of citizens in the assessment of police activities has a positive effect on cooperation between society and the police, reduces their contempt for each other, as both society and police are interested in reducing crime and improving protection from criminal encroachment.

However, the level of public confidence is not the only criterion for assessing the activities of the police and other law enforcement agencies, and therefore we suggest paying attention to the experience of Canada, where the basis for assessing the police are two indicators:

a) strategic (assessment of the impact of police activities on the state of crime in the state, the level of public confidence in the police).

b) operational (quantitative indicators of police activity contained in annual plans and reports on their activities).

At present, the assessment of police in Canada uses the method of ongoing improvement of service quality, which is used to evaluate all types of government agencies and institutions. This method involves a comprehensive assessment of the environment of a public body or institution, which is a system where leadership, strategic planning, cooperation with citizens, management of available resources and the end results of these bodies and institutions are closely linked (Lelandais and Bodson, 2007). 


\section{8}

Vira Halunko, Oleh Shkuta, Oleh Predmestnikov, Nataliia Petrenko y Nina Holenko International Experience in Assessing the Effectiveness of Law Enforcement Agencies in Crime Prevention

In the USA, police assessment has the following components: qualitative assessment (individual and police unit) and quantitative indicators. Individual assessment of a police officer's activity is based on an annual attestation, during which the immediate supervisor provides a qualitative assessment of the subordinate's work and his professional progress according to a set of criteria defined by the regulations on the activities of a particular police department. Such criteria are attention and concentration, communication skills, resilience to stressful situations, flexibility and ability to work with different people, knowledge, ability to learn, initiative and more. Not only the scores for each criterion are indicated, but also the descriptive characteristics for each of them.

The USA police departments (separate territorial units within large city departments) are evaluated by two conflicting systems. On the one hand, there are standard statistics that are convenient for bureaucratic reporting; on the other, assessment by locals is becoming increasingly popular with the spread of the concept of "community policing". Accordingly, along with the traditional reporting system, there is a practice of population surveys. They range from basic "community feedback forms" (mostly on websites) to comprehensive surveys that assess local priorities, expectations of the police, compliance of actual police activities with these priorities and expectations, real safety of life in the district and security by feel. Only an indicator adopted by an elected body and announced as an official indicator in advance can acquire the status of an official assessment.

The problem of quantifying the performance of the USA police unit, as well as an individual employee, occurs in the largest police departments, where the number of staff is significant, and the territory of the municipality is divided into sections. Criteria used in the following cases:

a) the percentage of opened cases against registered;

b) the ratio of the number of arrests to the number of registered crimes;

c) the number of detected crimes and the dynamics of their indicators (Krapyvin, 2016).

In France, statistics on police performance are also taken into account when assessing their performance. In particular, in 2002, the French police introduced an approach such as a "culture of result", which significantly changed the way the police generate statistics. According to this approach, the highest police body sets quantitative targets for lower levels, as well as establishes a system of bonuses for achieving them. At the same time, each level of police activity has its own form of statistical data tables, which are the basis of police reports. Accordingly, after receiving the reports, crime statistics are compared with the activities of the police and the resources available to them. 
At the same time, this model of activity and assessment of the French police is not supported by all scientists. Among them are those who point out that statistics without independent verification are a questionable indicator of police performance. The lack of an independent audit of statistics at the local level allows the police to be a monopolist in the production of crime statistics and creates the necessary conditions for the manipulation of statistics (Eterno and Silverman, 2012; Nazarova et al., 2019).

One form of assessing the effectiveness of law enforcement in the United States is to accredit a law enforcement agency by an independent institution on its own initiative, as accreditation is a right, not a duty, of a law enforcement agency.

This accreditation is conducted by the board of an independent nonprofit organization - CALEA, consisting of 21 people, 11 of whom have practical experience in law enforcement. The essence of accreditation is a set of actions aimed at establishing compliance of the organization and activities of US law enforcement agencies with various standards in the main areas of their activities.

These standards, according to I. M. Osyka, help law enforcement agencies:

- to improve opportunities for crime prevention and control of the service area;

- to formalize the basic management procedures;

- to establish a fair and non-discriminatory treatment of staff and normalize relations in the team;

- to improve the level of services provided to the population;

- to change coordination and interaction with other law enforcement agencies;

- to increase the reputation in the eyes of the population and the employees themselves (Osyka, 2015). It is obvious that the accreditation of law enforcement agencies still has its advantages.

At the same time, the accreditation process involves five stages. The first stage involves acquainting the law enforcement agency with information about accreditation and registration for accreditation. After registration, the second stage begins, at which the law enforcement body signs the accreditation agreement and within 24-36 months from the date of its conclusion carries out self-assessment. Upon completion of the selfassessment phase, the law enforcement authority informs CALEA and proposes to set a date for the start of the on-site assessment. The third stage of accreditation involves the assessment of the organization and 
Vira Halunko, Oleh Shkuta, Oleh Predmestnikov, Nataliia Petrenko y Nina Holenko

International Experience in Assessing the Effectiveness of Law Enforcement Agencies in Crime

activities of law enforcement by a team of CALEA experts on site. That is, a team of experts directly located at the location of the law enforcement agency, analyzes information about its activities, examines the necessary documents, conducts public discussions and formulates final conclusions on the results of accreditation. This is followed by the fourth stage, in which, if the law enforcement agency meets all the standards of organization and activities, CALEA confirms this with an official opinion, which is valid for three years. After receiving this confirmation, the fifth stage begins - the law enforcement agency within three years from the date of accreditation must monitor the compliance of its organization and activities with the standards, provide evidence to support this. In addition, an annual report must be submitted to CALEA.

This experience is undoubtedly progressive, but its implementation is possible only in a democratically developed country, where all the principles of democracy are implemented, and the public takes an active part in law enforcement, in particular, informs the subjects of criminal offenses, provides assistance in identifying and the investigation of certain socially dangerous acts, and the management and employees of law enforcement agencies are also aware of their purpose - to act solely in the interests of society, and their activities are transparent to the public.

Accordingly, in the United States, the accreditation of law enforcement agencies is provided in the form of a right, not an obligation. Unfortunately, in Ukraine it is virtually impossible to implement the US experience in this way today. At the same time, if we talk about the mandatory accreditation of law enforcement agencies, then there are many issues without which it can not be carried out. First of all, we are talking about the development of appropriate standards of law enforcement, as well as the creation of a new entity - a state-authorized body or institution that will verify compliance with law enforcement of Ukraine to certain standards, after they conduct self-assessment. However, given the reality of democracy in Ukraine, as well as reforming the law enforcement system, in particular those that are the subjects of financial and economic security of the state (Tamosiuniene et al., 2019; Yankovyi et al., 2020), we consider it impractical to implement the US experience in accrediting law enforcement agencies in Ukraine.

One of the leaders in assessing the effectiveness of policing today is Northern Ireland, which has a Policing Council, an independent public body tasked with ensuring the effective and impartial operation of a police service that is trusted by the entire population. Given the main purpose of this council, monitoring the effectiveness of the police to improve the interaction between the police and society is one of its main responsibilities. Surveys of citizens' trust in the police are conducted by the Police Council twice a year, and their main focus is to find out the level of citizens' trust in the police, which is established not by asking a direct question of trust 
or distrust in the police, but focuses on victimization, ie on the attitude of citizens to the police, on the data on how a police officer behaves in an emergency situation, the experience of citizens' appeals to the police and the level of effectiveness of the assistance received. In addition, the results of the sociological study are open to the public (Davis, 2012).

In the United Kingdom (except Scotland), since 1996, the main body that evaluates the work of the police is the Police Inspectorate, which is not part of the government, is not part of ministries or police and reports directly to Parliament, and its inspectors appointed by the monarch. At the same time, policing in the UK is carried out at both national and local levels by Commissioners for Police and Crime. This position is quite specific, as the Commissioners for Police and Crime are elected by the population of the territory served by the relevant police unit. The task of the Commissioners for Police and Crime is to ensure the effectiveness of the relevant police unit, as they annually submit a report on the activities of the police unit, which includes information on the status of achievement of the objectives set by the plan (Sviatokum, 2013).

The UK Police Inspectorate may conduct external and internal surveys to assess police performance at the national level. It should be noted that the external survey is based on the PEEL methodology, according to which police activities are evaluated by:

- the criterion of effectiveness, ie how effectively the police prevent crimes, investigate the facts of crimes committed, compensate for the damage caused by them, as well as fight organized crime;

- the criterion of economy, ie how well the police use their resources to meet the demand for police services, meet the organizational and financial requirements for the police, as well as the financial position of the police in the short and long term;

- the criterion of legality, ie whether police officers comply with current legislation and ethical standards in the performance of their duties, how well-off police personnel are and how they interact with the public and the level of consideration of complaints and appeals by police officers (PEEL Assessment, 2015).

From the above we conclude that the assessment of the effectiveness of law enforcement in the UK (except Scotland) is based on qualitative and quantitative criteria. External and internal surveys also play an important role.

Other countries have taken into account the experience of the United Kingdom, one of which is Portugal. According to the concept of measuring the effectiveness of the Portuguese police, most attention is paid to assessing the results of their activities on the following indicators: 
Vira Halunko, Oleh Shkuta, Oleh Predmestnikov, Nataliia Petrenko y Nina Holenko
International Experience in Assessing the Effectiveness of Law Enforcement Agencies in Crime
352 Prevention

1. a sense of security;

2. a level of fear of crime;

3. a percentage of calls that were answered in the allotted time;

4. a number of complaints from citizens per 1,000 employees;

5. a reasonable percentage of complaints filed by citizens (Gomes and Mendes, 2013).

Although Scotland is part of the United Kingdom, the assessment of the activities of the police in its territory differs from that considered above. The most important feature is another list of criteria for assessing the effectiveness of the police, which is focused on setting and achieving goals and is called the Scottish Policing Performance Framework. This system contains four areas of assessment:

1. quality of services provided;

2. citizens' sense of security and safety;

3. criminal justice and the fight against crime;

4. efficiency of management and activity.

For each group of criteria, strategic goals are defined, the implementation of which is assessed by three groups of indicators: resources expended, measures taken and their results. At the same time, the indicators independently determined by the police are subject to audit by a specially authorized state body in order to establish their reliability.

At the same time, the activities of Scottish police units are also assessed through public opinion polls. Their main task is to supplement the official police statistics by surveying citizens about crimes they became aware of or victims of during the reporting period. First of all, it allows you to identify information about crimes that have not been reported to the police. In addition, the personal opinion of citizens on the effectiveness of the police is investigated (Buhaichuk, 2015).

Given Scotland's experience in assessing the effectiveness of policing, it should be noted that the focus of policing is on statistics, while public confidence surveys not only complement these data but also influence the formulation of conclusions on the effectiveness of the police in carrying out the tasks assigned to it by law.

\section{Conclusion}

Thus, summarizing the foreign experience of states in assessing the effectiveness of law enforcement agencies, we can draw the following 
conclusions:

1. the basis for assessing the effectiveness of law enforcement agencies of foreign countries is a set of quantitative and qualitative criteria, which are both: a) are closely interrelated;

2. b) conflict with each other, given that some criteria are beneficial for bureaucratic reporting, while others reflect the interests of the public;

3. public opinion as one of the criteria is becoming increasingly important in assessing the effectiveness of law enforcement agencies of foreign countries (eg, the Slovak Republic), and in the US, France, Japan, Austria and Italy, it is a traditional tool for assessing them;

4. ambiguous is the use of statistics in assessing the effectiveness of law enforcement agencies of foreign countries: a) there are countries where criminal statistics are a priority in determining the effectiveness of law enforcement agencies, while questioning its reliability due to lack of mechanisms to combat manipulation of statistics (France); b) in some countries, self-determined by law enforcement criminal indicators are subject to audit, which minimizes the risk of falsification of statistics (Scotland);

5. assessment of the effectiveness of law enforcement agencies in certain areas - the quality of services, a sense of security, the fight against crime, the quality of management (Scotland);

6. the US experience is exceptional, where the assessment of the effectiveness of law enforcement is carried out in the form of accreditation, which is not a duty but a right of law enforcement;

7. the experience of Northern Ireland and the United Kingdom (except Scotland) is positive, where the assessment of police activities is carried out by specially formed bodies - the Police Council, the Police Inspectorate.

\section{Bibliographic References}

ANDRIICHENKO, Nadiia. 2018. "Step forward improvement of police performance assessment as a subject of combating financial and economic crimes: experience of Ukraine and Slovakia” In: Bratislava Law Review. Vol. 2, No, 2, pp. 127-136.

BUHAICHUK, Kostiantyn. 2015. Criteria for assessing the work of police bodies of individual countries. Available online. In: http://police-reform.khpg. org/articles/kriteriyi_ocinki_roboti_organiv_policiyi_okremih_krayin n. Consultation date: 08/09/2019 (In Ukrainian). 
Vira Halunko, Oleh Shkuta, Oleh Predmestnikov, Nataliia Petrenko y Nina Holenko International Experience in Assessing the Effectiveness of Law Enforcement Agencies in Crime Prevention

CALEA. n.d. The Gold Standard in Public Safety. Available online. In: https:// calea.org/es. Consultation date: 08/09/2019.

DAVIS, Robert C. 2012. Selected International Best Practices in Police Performance Measurement. Available online. In: https://www.jstor. org/stable/10.7249/j.ctt1q60z7. Consultation date: 08/09/2019.

ETERNO, John A.; SILVERMAN, Eli B. 2012. The crime numbers game. Management by Manipulation. CRC Press. New York, USA.

GOMES, Patrícia; MENDES, Silvia. 2013. "Performance measurement and management in Portuguese law enforcement" In: Public Money\&Management. Vol. 33, No.1, pp. 31-38.

GORDEEV, Aleksej. 2017. "On the issue of positive experience in crime prevention in foreign countries" In: Issues of Russian and international law. Vol. 7, No. 11, pp. 115-121.

KRAPYVIN, Yevhenii. 2016. Assessment of police efficiency in Ukraine: from "sticks" to the new system. on the example of pre-trial investigation bodies): scientific and practical publication. Sophia-A. Kyiv, Ukraine.

LELANDAIS, Isabelle; BODSON, Julie. 2007. "Measuring police performance: International Experiences" In: National criminal justice reference service. Available online. In: https://www.ncjrs.gov/App/publications/ Abstract.aspx?id=246628. Consultation date: 08/09/2019.

LOSHITSKII, Mykola. 2015. About the experience of policing in the USA, Great Britain and Canada. Actual problems of administrative law and administrative process in Ukraine: materials of All-Ukrai. scient.-pract. conf. Dnipropetrovsk, pp. 11-14.

LUM, Cynthia. 2009. "Community Policing or Zero Tolerance? Preferences of Police Officers from 22 Countries in Transition” In: British Journal of Criminology. Vol. 49, No. 6, pp. 788-809.

MCCOLD, Paul; WACHTEL, Ben. 1996. "Police officer orientation and resistance to implementation of community policing" In: American Society of Criminology. Available online. In: https://www.ncjrs.gov/pdffiles1/ Digitization/165617NCJRS.pdf. Consultation date: 08/09/2020.

NAZAROVA, Karina; HORDOPOLOV, Volodimir; KOPOTIIENKO, Tetiana; MINIAILO, Viktoriia; KOVAL, Viktor; DIACHENKO, Yuliia. 2019. "Audit in the state economic security system" In: Management Theory and Studies for Rural Business and Infrastructure Development, Vol. 41, No. 3, pp. 419-430. 
OSYKA, Igor. 2015. Criteria for assessing the effectiveness of law enforcement: the experience of the United States and the United Kingdom. Available online. In: http://police-reform.khpg. org/articles/index. php?do=print\&id=1433232742. Consultation date: 12/03/2020.

PEEL ASSESSMENT. 2015. Available online. In: https://www. justiceinspectorates.gov.uk/hmi cfrs/peel-assessments/how-weinspect/2015-peel-assessment/. Consultation date: 12/03/2020.

SVIATOKUM, Igor. 2013. "The experience of the United Kingdom in the field of assessing the effectiveness of police activities and prospects for its use in Ukraine" In: Law and security. Vol. 1, No. 48, pp. 64-49.

TAMOSIUNIENE, Rima; DEMIANCHUK, Maryna; KOVAL, Viktor. 2019. "State regulation of bankruptcy relations in the national economy" In: Economics. Ecology. Socium. Vol. 3, No. 4, pp. 19-27.

YANKOVYI, Oleksandr; KOVAL, Viktor; TROKHYMETS, Olena; KARPENKO, Maryna; MATSKEVICH, Yuliia. 2020. "Economic assessment of investment on the basis of production functions" In: Turismo: Estudos \& Práticas. Available online. In: http://natal.uern.br/periodicos/index. php/RTEP/article/view/1310. Consultation date: 12/03/2020. 
ISSN 0798-1406 Depósito legal pp 198502ZU132

\section{Cuestiones Políticas}

\section{Planilla de suscripción}

Nombre

Institución

Dirección

Ciudad País

Cheque de gerencia a nombre de: Universidad del Zulia (LUZ),

Facultad de Ciencias Jurídicas y Políticas, Ingresos Propios

Banco Occidental de Descuento, Cuenta corriente № 212700890-9

Tarifa de suscripción por un año (dos números):

Venezuela: Bs. 80 + Envío

Ejemplar solo: Bs. $40+$ Envío

América Latina \$ $40+$ Envío

Resto del mundo $\$ 50+$ Envío

Esta planilla debe ser enviada a la siguiente dirección:

Revista "Cuestiones Políticas"

Facultad de Ciencias Jurídicas y Políticas

Instituto de Estudios Políticos y Derecho Público

Apartado Postal 526, Maracaibo Venezuela

Puede adelantar información por: cuestionespoliticas@gmail.com

loichirinosportillo@gmail.com 